Research article

\title{
Modelling the ex situ bioremediation of diesel-contaminated soil in a slurry bioreactor using a hydrocarbon-degrading inoculant
}

\author{
María Balseiro-Romero $^{\mathrm{a}, \mathrm{b}, *}$, Carmen Monterroso ${ }^{c}$, Petra S. Kidd ${ }^{\mathrm{d}}$, Thelmo A. Lu-Chau ${ }^{\mathrm{a}}$, \\ Panagiotis Gkorezis ${ }^{\mathrm{e}}$, Jaco Vangronsveld ${ }^{\mathrm{e}}$, Juan J. Casares ${ }^{\mathrm{f}}$ \\ ${ }^{a}$ Department of Chemical Engineering, Institute of Technology, Universidade de Santiago de Compostela, 15782, Santiago de Compostela, Spain \\ ${ }^{\mathrm{b}}$ UMR ECOSYS, AgroParisTech, Université Paris-Saclay, Avenue Lucien Brétignières, 78850, Thiverval-Grignon, France \\ ${ }^{\mathrm{c}}$ Department of Soil Science and Agricultural Chemistry, Faculty of Biology, Universidade de Santiago de Compostela, 15782, Santiago de Compostela, Spain \\ d Instituto de Investigacións Agrobiolóxicas de Galicia (IIAG), Consejo Superior de Investigaciones Científicas (CSIC), 15705, Santiago de Compostela, Spain \\ ${ }^{\text {e } C e n t r e ~ f o r ~ E n v i r o n m e n t a l ~ S c i e n c e s, ~ U n i v e r s i t y ~ o f ~ H a s s e l t, ~ B E 3590, ~ D i e p e n b e e k, ~ B e l g i u m ~}$ \\ ${ }_{\mathrm{f}}^{\mathrm{f}}$ Department of Chemical Engineering, School of Engineering, Universidade de Santiago de Compostela, 15782, Santiago de Compostela, Spain
}

\section{A R T I C L E I N F O}

\section{Keywords:}

Bio-slurry reactor

ex situ bioremediation

Diesel-contaminated soil

Sigmoid desorption kinetics

Monod biodegradation kinetics

\begin{abstract}
A B S T R A C T
Bioremediation is a soil clean-up technique which exploits the metabolic capacity of microorganisms to degrade soil contaminants. A model was developed to simulate the ex situ bioremediation of a diesel-contaminated soil in a bio-slurry reactor inoculated with a diesel-degrading bacterial strain. Mass transfer processes involving desorption of diesel from soil to water and volatilization of diesel from water, and biodegradation by the bacterial inoculant were included in the model by using Weibull sigmoid kinetics and logistic/Monod kinetics respectively. Model parameters were estimated in batch-based abiotic and biodegradation experiments. Sensitivity analysis revealed the importance of maintaining a high bacterial density in the system for maximum bioremediation efficiency. The model was validated using a pilot bioreactor monitored for $528 \mathrm{~h}$, which removed almost $90 \%$ of the diesel present in the system. The results revealed the capacity of the model to predict the bioremediation efficiency under different scenarios by adapting the input parameters to each system.
\end{abstract}

\section{Introduction}

In most industrialized countries, fuel is released into the environment, particularly to soil, during transportation and storage (Serrano et al., 2008). For example, many of hundreds of thousands of fuel stations across Europe have leaky tanks, from which fuel spills into the subsurface soil and may eventually reach aquifers (Day et al., 2001). As a result of public concern about this widespread pollution, soil remediation has been the subject of much research in recent years (Gan et al., 2009; Gkorezis et al., 2016; Khan et al., 2013; Tomei and Daugulis, 2013).

Bioremediation is considered an "environmentally-friendly" soil clean-up technology which has a low impact on soil functional properties, and the environment in general, and uses soil organisms (including plants, bacteria, and/or fungi) to degrade soil contaminants (Pilon-Smits, 2005). Bioremediation has been widely applied to restore petroleum-hydrocarbon polluted sites, both in situ (Gallego et al., 2001; Lors et al., 2012; Suja et al., 2014; Szulc et al., 2014) and ex situ
(Chemlal et al., 2013, 2012; Simpanen et al., 2016; Wang et al., 2016). In situ bioremediation is cheaper and easier to carry out than ex situ bioremediation and is preferable for ecological restoration (Megharaj et al., 2011); however, it usually takes longer to achieve acceptable levels of residual contaminants. Ex situ techniques are usually preferred when safe, quick and effective remediation need to be applied, as in the following cases: (a) highly contaminated soils with toxic and/or recalcitrant contaminants, in order to prevent contamination of other environmental compartments and also ecotoxic effects on flora and fauna (Tomei and Daugulis, 2013); (b) soils with low hydraulic conductivity, low permeability and high organic matter contents; (c) soils in regions characterised by adverse environmental conditions, which do not naturally favour bioremediation (e.g. cold regions); and (d) contaminated soils that require rapid remediation due to regulation pressures (Robles-González et al., 2008).

Ex situ bioremediation in slurry-phase bioreactors is one of the most efficient options for the clean-up of organic contaminants. In this system, contaminated soil is suspended in a nutrient-water solution in

\footnotetext{
* Corresponding author. Department of Chemical Engineering, Institute of Technology, Universidade de Santiago de Compostela, 15782, Santiago de Compostela, Spain.

E-mail addresses: maria.balseiro@usc.es, maria.balseiro.romero@gmail.com (M. Balseiro-Romero).
} 
the presence of indigenous or exogenous bacteria and is mixed thoroughly and aerated. These conditions promote significant enhancement of contaminant degradation and a significant reduction in the remediation time (Nano et al., 2003; Pino-Herrera et al., 2017; RoblesGonzález et al., 2008; Venkata Mohan et al., 2009) for the following reasons: (a) the liquid in the slurry facilitates contact between soil contaminants and the inoculants (through continuous agitation) and enhances mass transfer phenomena of the contaminants (in gas/liquid and solid/liquid interfaces), thus increasing contaminant bioavailability; (b) the toxicity of organic pollutants can be reduced by the addition of water (through a dilution effect) (c) the parameters (e.g., $\mathrm{pH}$, temperature and redox conditions); can be more easily controlled and optimized; and (d) different electron acceptors and solvents or surfactants can be used to enhance pollutant bioavailability. Slurry bioremediation generally relies on the stimulation of soil indigenous communities (i.e., biostimulation) through optimal growth conditions. The ex situ method also represents a promising opportunity to use exogenous degrading bacteria with demonstrated metabolic capacities (i.e., bioaugmentation), while avoiding the concerns about ecological stress associated with in situ techniques (Mosca Angelucci and Tomei, 2016; Tyagi et al., 2011; Wang et al., 2016). Furthermore, it may be used as a prior step to determine the bioremediation potential: under controlled conditions, degradation rates depend mainly on the degradation efficiencies of the microorganisms present (Robles-González et al., 2008).

Ex situ bioremediation has also some drawbacks such as the need to excavate the soil and to construct and operate the bioreactor, with the derived extra costs relative to simple in situ bioremediation techniques. Nonetheless, slurry bioremediation is often more cost effective and environmentally friendly than soil incineration, soil washing or thermal desorption (Castaldi, 2003; Robles-González et al., 2008).

Modelling bio-slurry reactor processes can be useful for designing and determining the efficiency of bioremediation procedures, and it can be used to establish the required microbial biomass inputs, the time to achieve remediation objectives and the influence of soil properties on remediation efficiency. The efficiency is mainly evaluated on the basis of the time required to achieve an acceptable concentration of contaminants in soil, in which System Dynamics-based models can play an important role. Several bioremediation models have already been described (Borsi and Fasano, 2009; Fernández et al., 2016). These models generally assume simple first-order desorption kinetics, which may not accurately predict complex desorption from soils. This process is usually delayed during the initial stages due to sorption forces exerted by soils, which follow a sigmoid distribution (Skrdla, 2007). Furthermore, biodegradation is usually only modelled by a Monod function, which may not accurately predict logistic bacterial growth and substrate utilization in slow desorption and bioavailability-limited systems such as soil.

The objective of the present research was to formulate a model based on the System Dynamics technique to simulate the bioremediation of a diesel-contaminated soil in a bio-slurry reactor system through bioaugmentation mediated by an inoculant with demonstrated dieseldegrading capacity. The model integrated mass-transfer processes between phases (soil, water, air), including sigmoid desorption kinetics from soil, and degradation by inoculated bacteria following logistic and Monod kinetics, to evaluate the bioremediation efficiency over time. The model was validated using the monitoring data from a pilot-scale bioreactor.

\section{Materials and methods}

\subsection{Description of the bioremediation scenario and model assumptions}

The system under study comprised a completely stirred bioreactor containing a slurry of a diesel-contaminated soil and aqueous nutritive medium $(1: 4, w / w)$, which was inoculated with a diesel-degrading

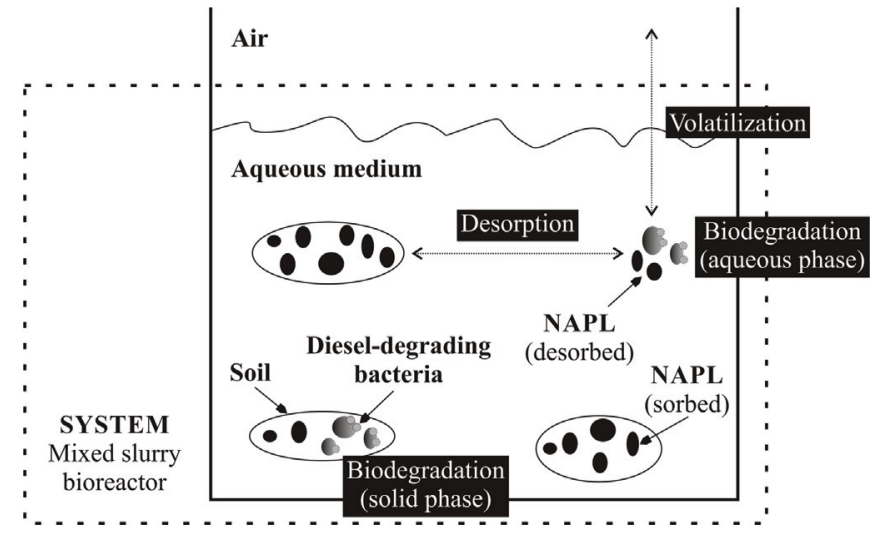

Fig. 1. Scheme of the system phases and the processes involved.

bacterial strain. Four phases were identified in the system: (a) a dieselcontaminated solid phase (soil); (b) a non-aqueous phase liquid (NAPL), corresponding to diesel sorbed and/or retained in soil pores and desorbed (but not dissolved) in water; (c) an aqueous phase, corresponding to water, i.e., the nutritive medium; and (d) a gaseous phase, open to system surroundings (Fig. 1). The system was completely mixed, and several mass-transfer and degradation processes taking place in the slurry were considered: (i) diesel dissolution and desorption from the solid to liquid phase, striving towards equilibrium; (ii) diesel volatilization to atmospheric surroundings from aqueous phase; and (iii) biodegradation of diesel (both in solid and aqueous phases), which will reduce the hydrocarbon concentration and modify soil-water equilibrium distribution (Fig. 1).

Several assumptions were made in formulating the model:

- Microbes were considered to be homogeneously distributed throughout the system, with access to diesel in both solid and aqueous phases of the slurry. Degradation was not considered to occur in the air compartment.

- Microbial growth or bacterial density $(B D)$ in the slurry was modelled following the Verhulst logistic Equation (Kargi, 2009) and assumed constant once asymptotic growth was reached (Equation (1)):

$\frac{d B D}{d t}=B D_{0}+k_{l} \cdot B D \cdot\left(1-\frac{B D}{B D_{\max }}\right)$

where $B D$ is the bacterial density in the system (colony forming units per $\mathrm{kg}$ of dry soil, $\left.\mathrm{CFU} \mathrm{kg}{ }^{-1}\right), B D_{0}$ is the initial bacterial density at the time of inoculation ( $\mathrm{CFU} \mathrm{kg}{ }^{-1}$ ), $B D_{\max }$ is the maximum bacterial density reached under the given system conditions $\left(\mathrm{CFU} \mathrm{kg}{ }^{-1}\right.$ ), and $k_{l}$ is a constant parameter from logistic function $\left(\mathrm{h}^{-1}\right)$.

- Biodegradation of diesel from both the solid and liquid phases was modelled according to Monod kinetics of substrate uptake (Equation (2)):

$\frac{d C}{d t}=\left(\frac{\mu_{\max } \cdot C}{K_{s}+C} \cdot \frac{B D}{\gamma}\right)$

where $C$ is the substrate (i.e., diesel) concentration in soil or water (hereafter named, respectively, $C_{s}$ or $C_{w}, \mathrm{mg} \mathrm{kg}^{-1}$ or $\mathrm{mg} \mathrm{L}^{-1}$ ), $\mu_{\max }$ is the maximum specific growth rate $\left(\mathrm{h}^{-1}\right), K_{s}$ is the saturation or halfrate constant ( $\mathrm{mg} \mathrm{kg}^{-1}$ or $\mathrm{mg} \mathrm{L}^{-1}$ ), and $\gamma$ is the growth yield coefficient (CFU mg ${ }^{-1}$ of substrate). BD was included as in Equation (1).

- Diesel desorption from soil to aqueous phase followed a sigmoid distribution over time, in which the concentration of diesel in water followed the Weibull function (Skrdla, 2007) (Equation (3)):

$C_{w}=C_{w \max } \cdot\left(1-e^{-\left(k_{w b} \cdot\right)^{n}}\right)$ 


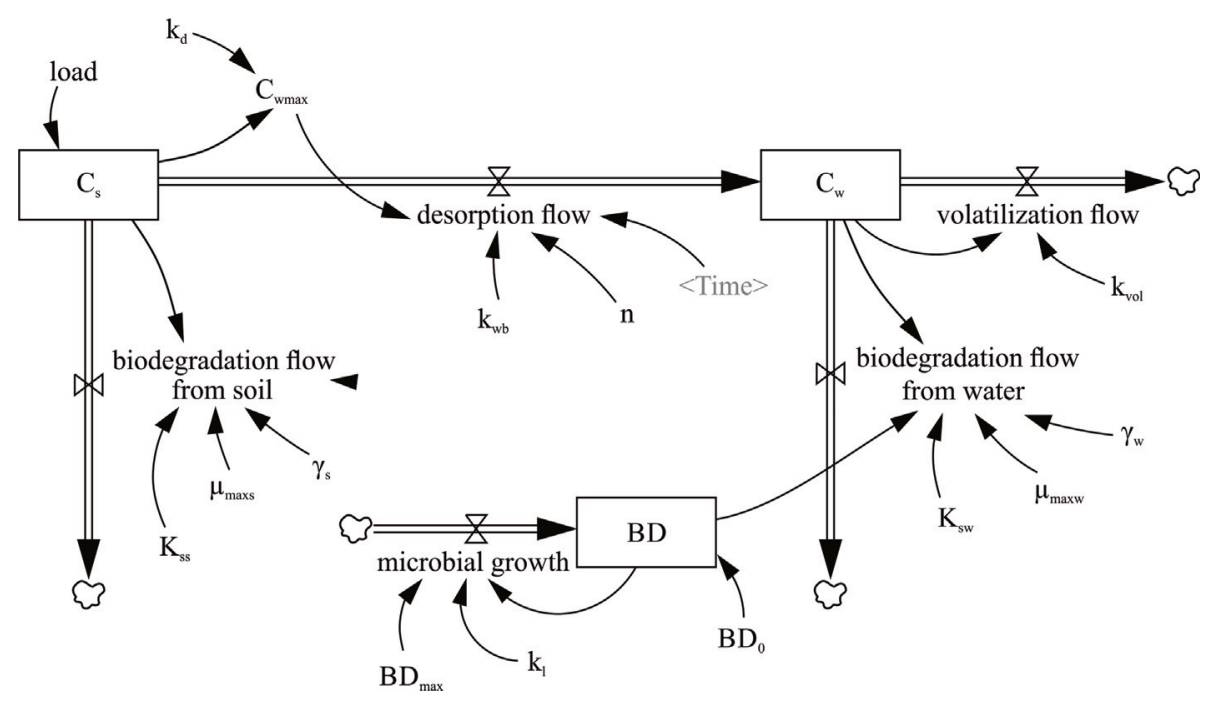

Fig. 2. Stock-and-flow diagram of the model constructed using Vensim software.

where $C_{w}$ is the concentration of diesel in the aqueous phase (either dissolved or as dispersed NAPL phase) $\left(\mathrm{mg} \mathrm{L}^{-1}\right), C_{w \max }$ is the maximum concentration of diesel in the aqueous phase $\left(\mathrm{mg} \mathrm{L}^{-1}\right)$, and $k_{w b}$ and $n$ are the kinetic parameters obtained from Weibull fitting.

- Volatilization was only considered to occur in the aqueous phase (i.e., from desorbed or dissolved diesel), as volatilization from soil was hindered by sorption forces and water solvation. Volatilization followed first-order kinetics (Equation (4)):

$\frac{d C_{v}}{d t}=-k_{v o l} \cdot C_{w} \cdot f$

where $C_{v}$ is the concentration of volatilized diesel $\left(\mathrm{mg} \mathrm{kg}^{-1}\right), k_{v o l}$ is the first-order kinetic constant of volatilization of diesel from the aqueous phase $\left(\mathrm{h}^{-1}\right)$ and $f$ is the constant mass ratio between water and dry soil $\left(\mathrm{L} \mathrm{kg}^{-1}\right)$.

\subsection{Model formulation}

The total variation in the diesel concentration in the system can be expressed as the sum of the variations in diesel concentrations of each phase considered (Equation (5)):

$\frac{d C}{d t}=f \frac{d C_{w}}{d t}+\frac{d C_{s}}{d t}+\frac{d C_{v}}{d t}$

where $C$ is the total concentration of diesel in the system ( $\mathrm{mg} \mathrm{kg}^{-1}$ ), and $C_{s}$ is the concentration of diesel in soil (either sorbed or as free NAPL trapped in pores) $\left(\mathrm{mg} \mathrm{kg}^{-1}\right)$.

On the basis of the System Dynamics methodology, we identified the variables as (a) stocks or levels, i.e., variables in which positive or negative accumulation takes place; (b) flows, i.e., variables that induce a variation in a stock value with time, (c) and auxiliary, i.e., variables that enable the calculation of other variables.

According to our assumptions and to the fact that the fraction of diesel volatilized is very small compared to solid or aqueous phases, two principal stocks were considered: diesel in the aqueous phase (which will include both dissolved diesel and non-dissolved free NAPL phase) and diesel in the soil phase (which will include both sorbed diesel and free NAPL phase occluded in pores).

The variation in diesel concentration in the aqueous phase $\left(C_{w}\right)$ corresponds to the sum of mass transfer flows between phases (desorption and volatilization) and biodegradation by the inoculated bacterial strain. The concentration in the liquid phase will increase due to desorption from the soil phase and decrease due to volatilization and biodegradation. These processes will stimulate desorption, which will tend to equilibrate with soil (Equation (6)):

$\frac{d C_{w}}{d t}=\frac{C_{w \max } \cdot n \cdot\left(k_{w b} \cdot t\right)^{n-1}}{e^{\left(k_{w b} \cdot t\right)^{n}}}-k_{v o l} \cdot C_{w}-\frac{\mu_{\operatorname{maxw}} \cdot C_{w}}{K_{s w}+C_{w}} \cdot \frac{B D}{\gamma_{w}}$

where the first term corresponds to desorption flow (equation (3) time derivative), the second term to volatilization flow and the third term to biodegradation flow; and $\mu_{\operatorname{maxw}}$ is the maximum specific growth rate in water $\left(\mathrm{h}^{-1}\right), K_{s w}$ is the saturation or half-rate constant of bacteria colonizing the aqueous phase ( $\mathrm{mg} \mathrm{L}^{-1}$ ), and $\gamma_{w}$ is the growth yield coefficient of bacteria colonizing the aqueous phase (CFU mg ${ }^{-1}$ of diesel). $C_{\text {wmax }}$ is not a constant parameter in biodegradation experiments, as the concentration of diesel in soil and water is continuously changing due to biodegradation. $C_{w \max }$ was therefore calculated as a function of soil diesel concentration $\left(C_{s}\right)$ by using the partition coefficient of diesel between soil and water determined in desorption abiotic experiments ( $k_{d}$; dimensionless) (Equation (7)).

$k_{d}=\frac{C_{w \max } \cdot f}{C_{s}}$

The decrease in diesel concentration in the soil phase $\left(C_{s}\right)$ was due to desorption and biodegradation flows (Equation (8)):

$\frac{d C_{s}}{d t}=$ load $-f \frac{C_{w \max } \cdot n \cdot\left(k_{w b} \cdot t\right)^{n-1}}{e^{\left(k_{w b} \cdot\right)^{n}}}-\frac{\mu_{\operatorname{maxs}} \cdot C_{s}}{K_{s s}+C_{s}} \cdot \frac{B D}{\gamma_{s}}$

where load corresponds to the initial concentration of diesel in soil (mg $\mathrm{kg}^{-1}$ ), the second term corresponds to desorption flow (equation (3) time derivative), and the third term corresponds to biodegradation flow; $\mu_{\operatorname{maxs}}$ is the maximum specific growth rate in soil $\left(\mathrm{h}^{-1}\right), K_{s s}$ is the saturation or half-rate constant of bacteria colonizing the solid phase ( $\mathrm{mg} \mathrm{kg}^{-1}$ ), and $\gamma_{s}$ is the growth yield coefficient of bacteria colonizing the solid phase (CFU mg ${ }^{-1}$ of diesel).

A biodegradation model for diesel in a bioreactor system was developed using Vensim software (Ventana Systems, Inc.) based on the previous assumptions and equations. This software, based on System Dynamics technique, allows continuous simulation of the system over time. Fig. 2 shows the stock-and-flow diagram, used as the basis for constructing the model with the software. The stocks (represented by a square) were soil $\left(C_{s}\right)$ and aqueous $\left(C_{w}\right)$ diesel concentrations, and the bacterial density in the slurry $(B D)$; and the flows (represented by double arrows) were desorption, biodegradation from soil and water, volatilization from water, and microbial growth. Equation (1) (for microbial density stock), 6 (for diesel in water stock) and 8 (for diesel in soil stock) were included in the model, and the parameters (auxiliary variables connected with simple arrows to stocks and/or flows) were 


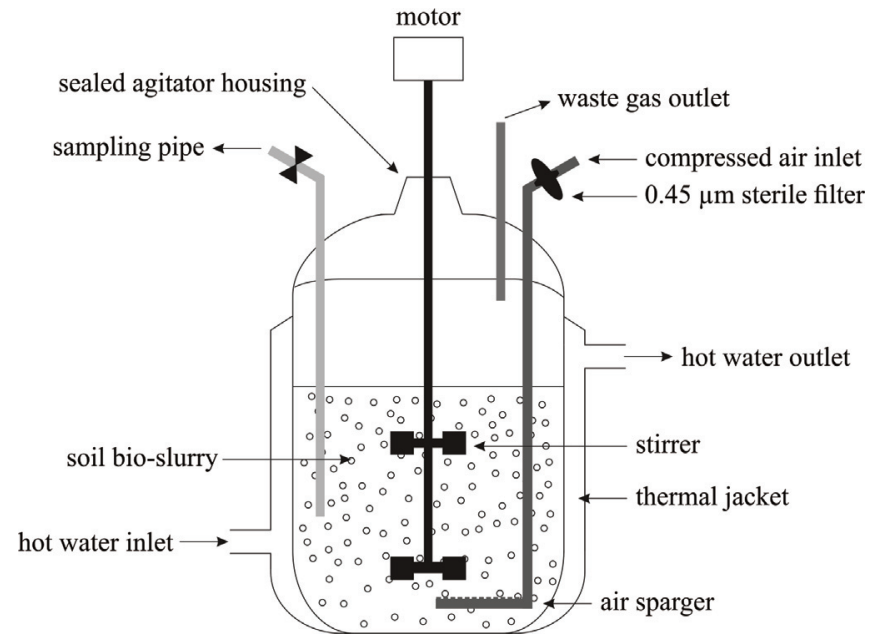

Fig. 3. Pilot-scale bio-slurry reactor used in the experiments.

estimated using laboratory-scale batch experiments (described in section 2.4). In order to unify the model units, the unit used for both stocks (soil and water) in the model was mg of diesel per $\mathrm{kg}$ of dry soil. Therefore, parameter $f$ described in the equations was already intrinsically included in $C_{w}$ and not directly included in the model as an auxiliary variable.

\subsection{Soil sample preparation}

A sample of the A horizon of a Cambic Umbrisol (IUSS Working Group WRB, 2014) collected in the surroundings of Santiago de Compostela (Galicia, NW Spain) was used for batch and bioreactor experiments. The sample was air-dried, sieved through a $2 \mathrm{~mm}$ mesh and kept in plastic containers at room temperature until use. This sample presented a variable charge, a sandy loam texture, an organic carbon content of $42.6 \mathrm{~g} \mathrm{~kg}^{-1}$, low $\mathrm{pH}$ (4.9) and low cation exchange capacity $\left(2.0 \mathrm{cmol}(+) \mathrm{kg}^{-1}\right)$, which was dominated by aluminium (standard methods for soil analyses following Pansu and Gautheyrou, 2006)).

The soil sample was sterilized (autoclaved 3 times $-121^{\circ} \mathrm{C}, 15 \mathrm{psi}$, 20 min-, with $24 \mathrm{~h}$ intervals) and artificially contaminated with $1.5 \%$ $(w / w)$ of diesel purchased in a local fuel station; the diesel was filtersterilized (PTFE $0.22 \mu \mathrm{m}$ filter; Millipore). Soil was kept in closed glass recipients and stabilised at $4{ }^{\circ} \mathrm{C}$ for 1 week before the experiments were established.

\subsection{Batch experiments for parameter estimation}

Laboratory-scale batch experiments (both abiotic and inoculated) were used to estimate the model parameters, as described in section 2.2: the desorption $\left(k_{d}, k_{w b}, n\right)$ and volatilization $\left(k_{v o l}\right)$ parameters were estimated in abiotic experiments; and the parameters of diesel biodegradation from soil $\left(\mu_{\operatorname{maxs}}, K_{s s}, \gamma_{s}, B D_{\max }\right.$ and $\left.k_{l}\right)$ were estimated in inoculated experiments. Only the parameters for biodegradation from water $\left(\mu_{\max w}, K_{s w}\right.$ and $\left.\gamma_{w}\right)$ were obtained from previous diesel biodegradation experiments in liquid media (Balseiro-Romero et al., 2017). The parameters were obtained by fitting the experimental data to the corresponding equations by using Origin software (OriginLab Corp.).

For abiotic experiments (without bacterial inoculation), a slurry of $2 \mathrm{~g}$ of contaminated soil and $8 \mathrm{~mL}$ of Bushnell Haas modified mineral medium (BH2) was prepared, under sterile conditions, in $25 \mathrm{~mL}-$ Pyrex centrifuge tubes $(n=3)$ ). $\mathrm{BH} 2$ medium contained (per L): $1.3 \mathrm{~g} \mathrm{~K}_{2} \mathrm{HPO}_{4}$, $1.0 \mathrm{~g} \mathrm{KH}_{2} \mathrm{PO}_{4}, 0.8 \mathrm{~g} \mathrm{NH}_{4} \mathrm{Cl}, 0.8 \mathrm{~g} \mathrm{NaNO}_{3}, 0.01 \mathrm{~g} \mathrm{FeSO}_{4} \cdot 7 \mathrm{H}_{2} \mathrm{O}$, and $0.4 \mathrm{~g}$ $\mathrm{MgSO}_{4} \cdot 7 \mathrm{H}_{2} \mathrm{O}$ (Bushnell and Haas, 1941). For biodegradation experiments (with bacterial inoculation), a slurry of $2 \mathrm{~g}$ of contaminated soil and $8 \mathrm{~mL}$ of $\mathrm{BH} 2$ mineral medium comprising $10 \%(v / v)$ of bacterial inoculum was established $(n=5)$ under sterile conditions. The inoculum used was a diesel-degrading bacterial strain (Acinetobacter calcoaceticus GK2; NCBI GenBank accession GCA_001510805.1) isolated from the rhizosphere of hybrid poplar (Populus deltoides $\mathrm{x}$ (trichocarpa $x$ deltoides) cv. Grimminge) growing on a diesel-contaminated soil in Genk (Belgium) (Gkorezis, 2014). This strain was selected due to its high degrading capacity in vitro: $80-90 \%$ of diesel range organics present in the liquid media were degraded after incubation for 10 days (Balseiro-Romero et al., 2017). Prior to being added to tubes, the inoculum was adjusted to an optical density ca. 1 at $590 \mathrm{~nm}$, corresponding approximately to an initial density of cells in the slurry of $2.96 \cdot 10^{9}$ colony forming units - CFU- per kg of dry soil or $7.4 \cdot 10^{8} \mathrm{CFU}$ per L.

In both experiments, tubes were incubated at $30^{\circ} \mathrm{C}$ and agitated at $150 \mathrm{rpm}$, and 3 or 5 replicates (depending on the experiment) were removed after $1,2,4,6,8,11,13$ and 15 days to monitor the desorption, volatilization and biodegradation processes.

\subsection{Bacterial density in batch biodegradation experiments}

In batch biodegradation experiments, an aliquot of soil slurry was used to determine bacterial densities at each monitoring time $(n=5)$. Aliquots of $100 \mu \mathrm{L}$ of serial ten-fold dilutions were plated in 1:10 diluted 869 agar medium. After incubation of the plates for 7 days at $28^{\circ} \mathrm{C}$, the CFUs were counted and extrapolated to per $\mathrm{kg}$ of dry soil or $\mathrm{L}$ of water in the slurry.

\subsection{Model validation in a pilot-scale system}

The bioremediation model was validated at pilot-scale using the monitoring data from a $2 \mathrm{~L}$ sterile, closed glass bioreactor enclosed in a thermal jacket (Fig. 3). The operational conditions are summarized in Table 1 . The bio-slurry reactor was constantly agitated using a stirrer with two flat impellers placed at two different heights to favour complete homogenization of the slurry. The stirring velocity chosen prevented the soil suspension from precipitating. The soil slurry was aerated using a small compressor and a porcelain porous sparger placed on the base of the reactor, which also favoured the suspension of soil particles. The temperature was maintained at $30 \pm 2{ }^{\circ} \mathrm{C}$ using a continuous flow of hot water (from a water bath) through the reactor thermal jacket. Before the experiment was established, the reactor and the lid were autoclaved, and the rest of materials used were sterilized under UV light for $1 \mathrm{~h}$.

The bioreactor was filled under sterile conditions with a soil bioslurry comprising $250 \mathrm{~g}$ of sterile diesel-contaminated soil and $1 \mathrm{~L}$ of BH2 nutritive medium, containing $10 \%(v / v)$ of the same degrading inoculum as used in batch experiments. The reactor tank was hermetically closed and the air entering the reactor was sterilized by passage through a $0.45 \mu \mathrm{m}$ sterile syringe filter (Millipore) to prevent external microbial contamination (Fig. 3). The bioremediation efficiency was monitored for 22 days $(528 \mathrm{~h})$. Every $24 \mathrm{~h}$, two aliquots of the slurry $(5 \mathrm{~mL})$ were sampled through the Teflon sampling tube with the aid of a $20 \mathrm{~mL}$ glass-syringe. A $1 \mathrm{~mL}$-aliquot was also sampled to determine the

Table 1

Design and operational details of the pilot bio-slurry phase reactor.

\begin{tabular}{ll}
\hline Operational parameters & Value \\
\hline Total cycle period & $528 \mathrm{~h}(22$ days $)$ \\
Aeration & air flow of $50 \mathrm{~L} \mathrm{~h}^{-1}$ \\
Stirring velocity & $350 \mathrm{rpm}$ \\
Total volume & $2 \mathrm{~L}$ \\
Operating volume & $1.2 \mathrm{~L}$ \\
Operating temperature & $30 \pm 2{ }^{\circ} \mathrm{C}$ \\
Slurry ratio (Soil/Water) & $1: 4\left(250 \mathrm{~g}\right.$ of soil $+1 \mathrm{~L}$ of $\mathrm{BH}_{2}$ medium $)$ \\
Initial concentration of inoculum & $10 \%(v / v)$, pure culture at $\mathrm{OD}_{590 \mathrm{~nm}}=1$ \\
\end{tabular}


exact amount of dry soil contained in the slurry at each monitoring time. Before and after sampling, the tube was hermetically closed to prevent external contamination of the reactor environment. The loss of slurry due to sampling was considered in subsequent calculations.

\subsection{Determination of concentrations of diesel in soil and water fractions of the slurry}

At each monitoring time in the batch and bioreactor experiments, the slurry sample was centrifuged at $2700 \mathrm{rpm}$ for $10 \mathrm{~min}$, and the soil and liquid phases were separated for differential extraction of diesel. In both cases, diesel fuel concentration was determined on the basis of a surrogate fraction including 14 representative $n$-alkanes, i.e., alkanes from 10 to 25 carbons, $\mathrm{C}_{10}-\mathrm{C}_{25}$, usually termed diesel range organics (DRO).

The total concentration of DRO in soil (dry basis) was estimated by extraction with hexane in an accelerated solvent extractor (ASE, Dionex) at $100{ }^{\circ} \mathrm{C}$ and $14 \mathrm{MPa}$, for $5 \mathrm{~min}$ and 2 extraction cycles, based on previous results (Balseiro-Romero and Monterroso, 2018) and following US Environmental Protection Agency guidelines (US EPA, 2007). The liquid phase was ultrasonically extracted with hexane (1:1, sample/hexane) for $1 \mathrm{~h}$ (Balseiro-Romero and Monterroso, 2018). Trace water in hexane extracts was eliminated with anhydrous sodium sulphate.

The concentration of diesel in the extracts was determined by gas chromatography (Model 450 GC, Agilent Technologies) coupled to mass spectrometry (GC/MS) (Model 220 MS, Agilent Technologies). Calibration of DRO was carried out with a standard mixture of $\mathrm{C}_{10}-\mathrm{C}_{25}$ $n$-alkanes (DRO mix, Dr. Ehrenstorfer). Several concentrations of the calibration standards were prepared in hexane: $0.1,0.25,0.5,0.75,1.0$, 2.5, 5, 7.5 and $10 \mathrm{mg} \mathrm{L}^{-1}$. Chromatographic separations were performed in a FactorFour VF-5ms EZ-Guard capillary column ( $30 \mathrm{~m} \times 0.25 \mathrm{~mm} \times 0.25 \mu \mathrm{m}$; Agilent Technologies) operated with the following oven temperature program: $40^{\circ} \mathrm{C}$ (held for $10 \mathrm{~min}$ ) to $300^{\circ} \mathrm{C}$, at $10^{\circ} \mathrm{C} \mathrm{min}^{-1}$. The injector was operated with a temperature ramp from $60{ }^{\circ} \mathrm{C}$ to $300{ }^{\circ} \mathrm{C}$ (held for $35 \mathrm{~min}$ ), at a rate of $200{ }^{\circ} \mathrm{C} \mathrm{min}{ }^{-1}$, and samples were injected in split/splitless mode (Balseiro-Romero and Monterroso, 2018).

\section{Results and discussion}

\subsection{Estimation of model parameters}

The model parameters required to formulate the diesel bioremediation model for slurry bioreactors are specified in Table 2. This table includes the numerical values and the estimation methods for each of the parameters included in the model (Fig. 2).

The parameters of microbial growth in the soil slurry were estimated by adjusting the experimental data to the Verhulst logistic equation (Equation (1)), reaching $2.75 \cdot 10^{10} \mathrm{CFU} \mathrm{kg}^{-1}$ of dry soil (i.e., the maximum bacterial density, $B D_{\max }$ ), which is one order of magnitude higher than the initial bacterial density $\left(B D_{0}\right)$ (Table 2).

The parameters used to simulate diesel biodegradation in soil and water were estimated in batch-based experiments and from previous data (Balseiro-Romero et al., 2017), by adjusting experimental data to the Monod equation (Equation (2)). Biodegradation kinetic parameters $\left(\mu_{\max }=0.001 \mathrm{~h}^{-1}\right.$ in water and $0.06 \mathrm{~h}^{-1}$ in soil; and $K_{s}=55.8 \mathrm{mg} \mathrm{L}^{-1}$ in water and $1123.2 \mathrm{mg} \mathrm{kg}^{-1}$ in soil) (Table 2) were within the same order of magnitude of those reported in the literature. Fernández et al. (2016) estimated $\mu_{\max }$ values for diesel biodegradation of between 0.0031 and $0.0146 \mathrm{~h}^{-1}$ in a closed batch reactor containing a soil slurry. Dahalan et al. (2014) reported a $\mu_{\max }$ of $0.039 \mathrm{~h}^{-1}$ for the biodegradation of diesel in a contaminated soil. Most studies use the same biodegradation parameters for both biodegradation of diesel in soil and water phases of the slurry, but the experimental data show that degradation did not occur at the same rate in these phases. In inoculated systems, the biodegradation potential was higher in the aqueous phase than in the solid phase, as the contaminants were less bioavailable in soil due to retention (Afzal et al., 2011). For example, the model predictions showed $10 \%$ degradation of diesel in soil and $70 \%$ degradation of diesel in water after $360 \mathrm{~h}$ of simulation (data not shown). This was also reflected by the difference between growth yield coefficients $(\gamma)$ in the water and soil phases: $1.58 \cdot 10^{7}$ CFUs of the bacterial strain were needed to degrade one $\mathrm{mg}$ of DRO from the liquid phase, while an amount one order of magnitude higher $\left(7.67 \cdot 10^{8} \mathrm{CFU}\right)$ was needed to degrade one mg of DRO in soil (Table 2).

The parameters used to simulate the desorption of diesel from soil to water desorption were estimated in the same batch experiments, but under abiotic conditions (no bacterial inoculant was added), by adjusting the experimental data to a Weibull sigmoid curve (Equation (3)). In this abiotic experiment, the equilibrium between soil and aqueous phases was reached in approximately $192 \mathrm{~h}$, with a concentration of diesel in water of $88.6 \mathrm{mg} \mathrm{L}^{-1}$ (data not shown and not directly used in the model).

\subsection{Long-term analysis of the model sensitivity}

The sensitivity of the model to selected process parameters was evaluated in long-term simulations with Vensim software (i.e., $1600 \mathrm{~h}$, approximately 67 days). In order to test the sensitivity of the model to the initial diesel concentration in soil (load) (Fig. 4a), three contamination scenarios were considered (maintaining the other parameters as specified in Table 2): i.e., $1.5 \%(w / w)$ (corresponding to $2001.31 \mathrm{mg}$ DRO $\mathrm{kg}^{-1}$ ), which is the concentration used in the experiments; and two different concentrations, $0.5 \%$ and $2.5 \%(w / w)$ (corresponding respectively to 667.10 and $3335.52 \mathrm{mg}^{\mathrm{DRO}} \mathrm{kg}^{-1}$ ).

Model predictions indicated that, regardless of the initial concentration, the initial phase of diesel elimination was characterised by a high degradation rate, which then gradually slowed down over time (Fig. 4a). As expected, the higher the initial concentration, the more time was needed to reduce the diesel concentration in the system: i.e. elimination of $50 \%$ of diesel in the system was reached in 16-17, 22-23 or $27-28$ days, considering respectively $0.5,1.5$ or $2.5 \%(w / w)$ of diesel as the initial concentration in the soil.

The influence of the maximum bacterial density $\left(B D_{\max }\right)$ on diesel elimination was also evaluated (Fig. 4b) using the value determined experimentally in batch biodegradation experiments $\left(2.75 \cdot 10^{10} \mathrm{CFU} \mathrm{kg}^{-1}\right)$, and two higher values, i.e., $5.50 \cdot 10^{10} \mathrm{CFU} \mathrm{kg}^{-1}$ (twice the experimental value) and $2.75 \cdot 10^{11} \mathrm{CFU} \mathrm{kg}^{-1}$ (one order of magnitude higher). This analysis reflected that microbial density has a highly significant influence on bioremediation efficiency, as the increase in this variable caused a dramatic decrease in the time necessary to eliminate diesel from the system: if the bacterial density was twice the experimental value, the required time to achieve $50 \%$ of diesel degradation would be reduced by $200 \mathrm{~h}$, while if the bacterial density was increased by one order of magnitude, the degradation would be reduced by $c a .400 \mathrm{~h}$. On the basis of these results, the microbial density appears to be the key parameter that should be controlled in order to ensure an acceptable level of biodegradation efficiency in real bioslurry reactor applications. The density should be kept as high as possible in the system, by periodical inoculations and maintenance of oxygen and nutrient concentrations under non-limiting conditions.

It should also be noted that this model was developed for a particular soil (A horizon of an Umbrisol with sandy loam texture), with a specific level of diesel contamination $(1.5 \% \mathrm{w} / \mathrm{w})$ and for a specific bacterial inoculant. However, it could easily be adapted for other scenarios (types of soil or other degrading inoculants, either a sole bacterial strain or consortium) by calculating the corresponding model parameters. 
Table 2

Values and estimation methods of parameters used for model resolution with Vensim software.

\begin{tabular}{|c|c|c|c|}
\hline Process & Parameter & Value $^{\mathrm{a}}$ & Estimation method \\
\hline Artificial contamination & load & $2001.31 \mathrm{mg}$ DRO kg ${ }^{-1}$ & Determined in soil at $\mathrm{t}=0$ by ASE extraction and GC/MS analysis \\
\hline \multirow[t]{3}{*}{ Microbial growth } & Initial bacterial density $\left(B D_{o}\right)$ & $2.96 \cdot 10^{9} \mathrm{CFU} \mathrm{kg}^{-1}$ & Determined from batch degradation experiments by $\mathrm{CFU}$ counting \\
\hline & Maximum bacterial density $\left(B D_{\max }\right)$ & $2.75 \cdot 10^{10} \mathrm{CFU} \mathrm{kg}^{-1}$ & $\begin{array}{l}\text { Verhulst logistic adjustments of biomass growth kinetics observed } \\
\text { in CFU counting (Equation (1)) }\end{array}$ \\
\hline & Logistic function constant $\left(k_{l}\right)$ & $0.045 \mathrm{~h}^{-1}$ & As $B D_{\max }$ (Equation (1)) \\
\hline \multirow[t]{3}{*}{ Biodegradation from water } & Maximum specific growth rate in water & $0.001 \mathrm{~h}^{-1}$ & $\begin{array}{l}\text { Estimated from previous biodegradation experiments in BH2 } \\
\text { liguid media (Balseiro-Romero et al. 2017) (Equation (2)) }\end{array}$ \\
\hline & Half-rate constant of bacteria in water & $55.8 \mathrm{mg} \mathrm{L}^{-1}\left(223.48 \mathrm{mg} \mathrm{kg}^{-1}\right)$ & As $\mu_{\max w}$ (Equation (2)) \\
\hline & $\begin{array}{l}\text { Growth yield coefficient of bacteria in } \\
\text { water }\left(\gamma_{w}\right)\end{array}$ & $1.58 \cdot 10^{7} \mathrm{CFU}$ mg $\mathrm{DRO}^{-1}$ & As $\mu_{\operatorname{maxw}}$ (Equation (2)) \\
\hline \multirow[t]{3}{*}{ Biodegradation from soil } & $\begin{array}{l}\text { Maximum specific growth rate of bacteria } \\
\text { in soil }\left(\mu_{\operatorname{maxs}}\right)\end{array}$ & $0.06 \mathrm{~h}^{-1}$ & Estimated from batch biodegradation experiments (Equation (2)) \\
\hline & Half-rate constant of bacteria in soil $\left(K_{s s}\right)$ & $1123.2 \mathrm{mg} \mathrm{kg}^{-1}$ & As $\mu_{\operatorname{maxs}}$ (Equation (2)) \\
\hline & $\begin{array}{l}\text { Growth yield coefficient of bacteria in soil } \\
\left(\gamma_{s}\right)\end{array}$ & $7.67 \cdot 10^{8} \mathrm{CFU} \mathrm{mg} \mathrm{DRO}{ }^{-1}$ & As $\mu_{\operatorname{maxs}}$ (Equation (2)) \\
\hline \multirow[t]{3}{*}{ Desorption from soil to water } & Soil-water partition coefficient $\left(k_{d}\right)$ & 2.8 (dimensionless) & Estimated from batch abiotic experiments (Equation (7)) \\
\hline & Weibull function parameter $\left(k_{w b}\right)$ & $0.007 \mathrm{~h}^{-1}$ & $\begin{array}{l}\text { Weibull sigmoid adjustment of desorption kinetics in batch abiotic } \\
\text { experiments (Equation (3)) }\end{array}$ \\
\hline & Weibull function parameter $(n)$ & 7.4 (dimensionless) & As $k_{w b}$ (Equation (3)) \\
\hline Volatilization & $\begin{array}{l}\text { First-order kinetic constant of } \\
\text { volatilization from aqueous phase }\left(k_{v o l}\right)\end{array}$ & $5 \cdot 10^{-5} h^{-1}$ & $\begin{array}{l}\text { First-order kinetics adjustment of volatilization in batch abiotic } \\
\text { experiments (Equation (4)) }\end{array}$ \\
\hline
\end{tabular}

${ }^{\text {a }}$ For parameter estimation, we used the sum of the concentrations of the diesel range alkanes (from 10 to 25 carbons, i.e. DRO). Units of model parameters are expressed in mg of DRO per kg of dry soil or L of aqueous phase.

\subsection{Model validation at pilot-scale using a bio-slurry reactor and causal tracing}

The model developed was validated with the monitoring data from a pilot bio-slurry reactor. Fig. 5 represents the biodegradation kinetics as the decrease in the total concentration of diesel in the system (corresponding to the sum of $C_{s}+C_{w}$ of DRO, in $\mathrm{mg} \mathrm{kg}^{-1}$ ), including experimental data (points) and model predictions (line). The model was simulated using the equations described and the parameters estimated from laboratory-scale batch experiments (Table 2), except $B D_{\max }$, which was adjusted to $1.85 \cdot 10^{11} \mathrm{CFU} \mathrm{kg}^{-1}$ to converge with experimental predictions. The maximum amount of microbial density reached in the system was probably higher in the pilot bioreactor than in batch experiments due to the favourable conditions for microbial growth (i.e., continuous aeration, higher operational volume and longer incubation time).

Fig. 5 shows that the model predictions accurately fit the monitored data from the pilot bioreactor. Pearson linear correlations between experimental data and model predictions of total diesel concentration were established. The data were fitted using a linear model, with a significant Pearson coefficient of $\mathrm{r}=0.97$ and slope of 0.99 (error $=0.06$ ), reflecting the similarity between experimental data and model predictions. Diesel was essentially removed from the system after $528 \mathrm{~h}$ ( $>90 \%$ of DRO), which reflects the high degradation efficiency of the bacterial inoculant. Furthermore, the high degradation rate indicated that the configuration and operational parameters of the bioreactor were favourable for diesel elimination and that the system could be scaled up to design an industrial-scale bioreactor. High efficiencies of hydrocarbon biodegradation in the same bio-slurry reactor configuration have also been reported by other authors. Venkata Mohan et al. (2009) reported that $90 \%$ of pyrene was degraded after $120 \mathrm{~h}$ in a bioslurry reactor using a wastewater sludge as a degrading inoculant. Alavi et al. (2014) found a degradation efficiency of more than $90 \%$ of total petroleum hydrocarbons (TPH) present in an oil-contaminated soil after 21 days, using a reactor in bio-slurry configuration containing bacterial communities isolated from different abandoned drilling pits. Maddela et al. (2016) eliminated more than $85 \%$ of TPH after 30 days of incubation of a soil slurry contaminated with crude oil at laboratoryscale, using a mixed culture of hydrocarbon-degrading bacteria and fungi.

\subsection{Comparative contribution of flows to diesel elimination and model causal tracing}

The simulated concentrations of diesel in soil $\left(C_{s}\right)$ and water $\left(C_{w}\right)$ phases in the pilot bio-slurry reactor are presented in Fig. 6, as well as the flows contributing to diesel accumulation and/or elimination from both stocks, and the causal tracing diagrams for each stock. The volatilization flow was not included in Fig. $6 \mathrm{~b}$ as the contribution to the water phase stock was insignificant (the maximum value reached for volatilization flow was only $0.001 \mathrm{mg} \mathrm{L}^{-1} \mathrm{~h}^{-1}$ ).

The concentration of diesel in soil stock presented an initial value (load) from which it decreased driven by desorption and biodegradation flows (Fig. 6a). The decrease in the soil diesel concentration was slower at the beginning of the simulation, when desorption and biodegradation flows were low. During this initial phase (following the sigmoid pattern), desorption was limited due to the sorption forces exerted by soil. They induced an activation energy barrier that affected the rate of contaminant dispersion and dissolution (Skrdla, 2007). Furthermore, the initial slow bacterial growth would limit degradation during the first few hours and may also have slowed down the biodegradation. After this initial step, the concentration of diesel in the soil decreased faster due to the increase in desorption and, especially, biodegradation flows. The flows decreased with the diesel concentration, thus slowing down the elimination of diesel until reaching a value close to zero. The desorption flow made a smaller contribution to the decrease in soil diesel concentration, probably due to the strong retention exerted by soil, which was also reflected in the low concentration of diesel in water (Fig. 6b). However, this flow may be underestimated: diesel desorption from soil was simulated using the parameters calculated from abiotic experiments, but the microorganisms in biotic systems will probably enhance hydrocarbon desorption. Biological degradation of organic contaminants is always limited by the low bioavailability of these, due to the low aqueous solubility, high hydrophobicity and strong sorption to soil (Bezza and Nkhalambayausi Chirwa, 2016). Soil microorganisms may excrete biosurfactants, which can alter soil sorption forces, increasing the desorption, solubility and therefore the bioavailability of organic contaminants (Xia et al., 2014). The increase in desorption caused by microorganisms (biodesorption) may favour the biodegradation of the contaminants in the slurry system, both by bacteria colonizing soil and aqueous phases, and, therefore, modify the relative 

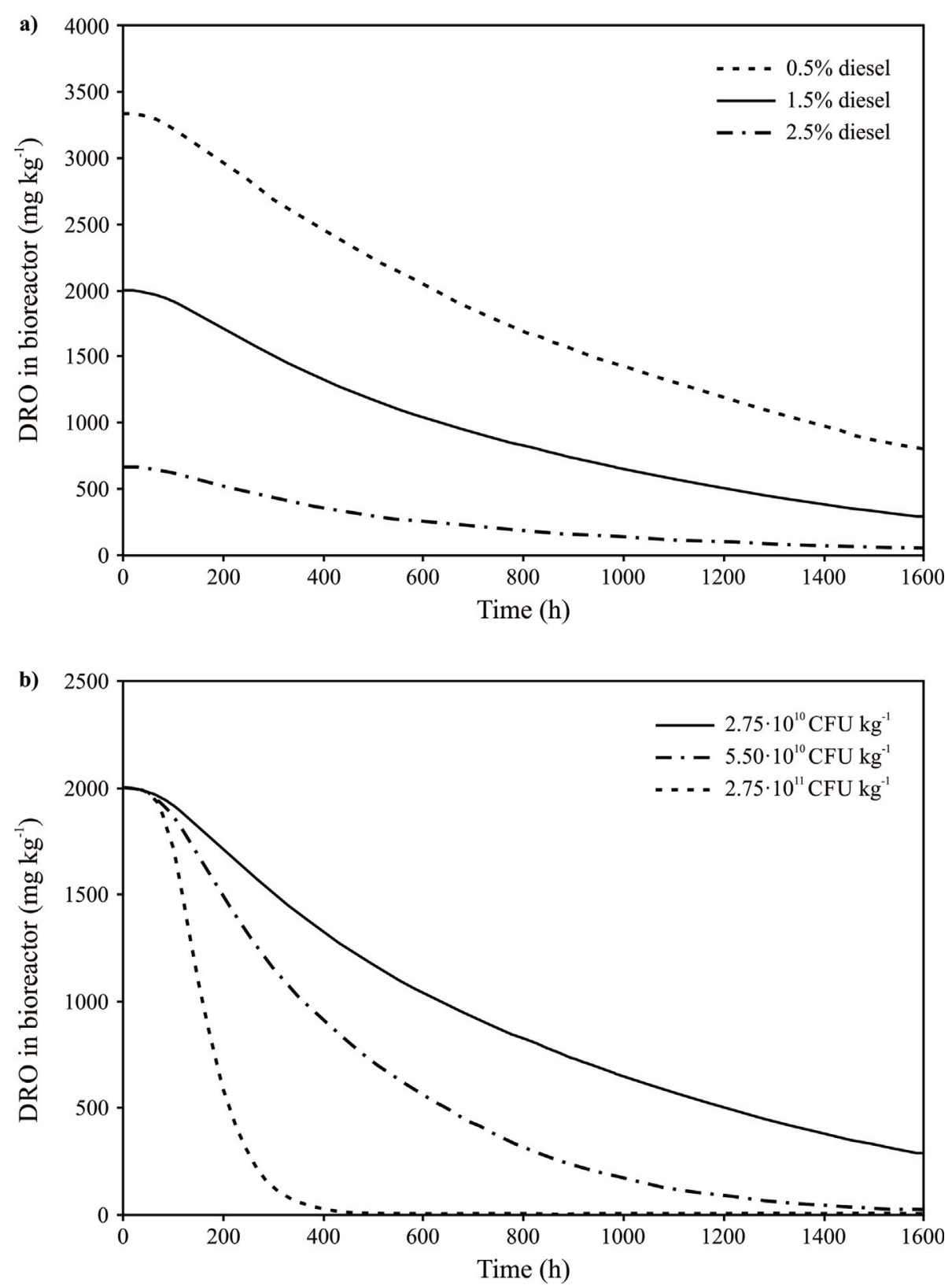

Fig. 4. Sensitivity analysis of long-term model simulations (from 0 to $1600 \mathrm{~h}$ ) of total diesel concentration in the slurry bioreactor (corresponding to the sum of $C_{s}+C_{w}$ of diesel range organics, DRO, in $\mathrm{mg} \mathrm{kg}^{-1}$ ), modifying (a) the initial diesel concentration in the soil (load) and (b) the maximum bacterial density ( $B D_{\max }$ ) reached in the system.

contributions of desorption and biodegradation flows to eliminating diesel from soil. This indicates that to be correctly simulated in complex bioremediation models, the effect of microbes on contaminant desorption and biodegradation flows should be further studied through laboratory-scale experiments. It is therefore also essential to prevent overestimation of biodegradation rates and unrealistic simulations.

The concentration of diesel in the aqueous stock increased, being driven by desorption flow until a maximum value ( $c a .19 \mathrm{mg} \mathrm{L}^{-1}$ ), after which it decreased dramatically (Fig. 6b). In the first step, the concentration of diesel in the aqueous stock increased because inflows (desorption) were higher than outflows (degradation and volatilization). The concentration in water decreased when the opposite occurred, and the small amount of diesel that was desorbed was rapidly degraded, thus impeding the accumulation in the stock. In the aqueous stock, biodegradation flow was relatively more intense (two orders of magnitude higher) than in soil, in which the diesel concentration was three orders of magnitude higher than biodegradation flow. This again reflected that biodegradation was preferably occurring in the aqueous phase, as the contaminants were more readily bioavailable than in soil (Semple et al., 2003). This was also observed in previous diesel degradation experiments in aqueous media, in which the same bacterial inoculant degraded $\mathrm{ca}$. $90 \%$ of DRO present in the medium after incubation for 10 days (Balseiro-Romero et al., 2017).

\section{Conclusions}

An ex situ soil bioremediation strategy in a bio-slurry reactor system was modelled for specific soil conditions and model assumptions. Sensitivity analysis reflected the significance of the bacterial density in the reactor on biodegradation kinetics and the importance of maintaining this parameter as high as possible to reduce the bioremediation time. The model was validated using a pilot-scale bioreactor, in 


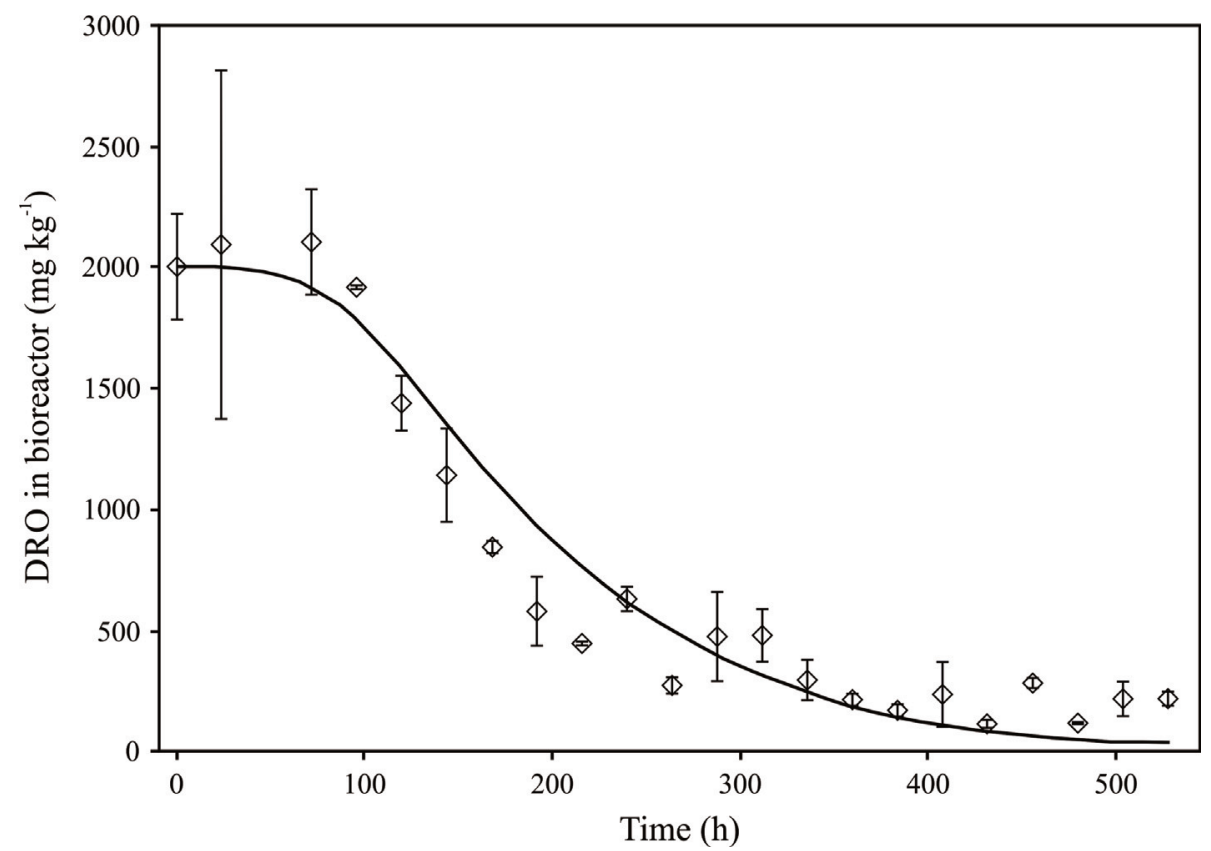

Fig. 5. Variation in total diesel concentration in the slurry bioreactor (corresponding to the sum of $C_{s}+C_{w}$ of diesel range organics, DRO, in mg kg ${ }^{-1}$ ) over time. Dots correspond to experimental data and the line represents model predictions up to $528 \mathrm{~h}$. Experimental data are represented as the mean \pm standard deviation.

a)

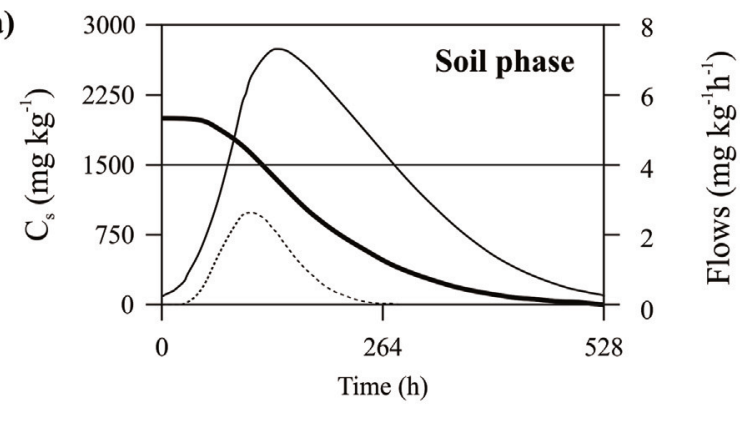

b)

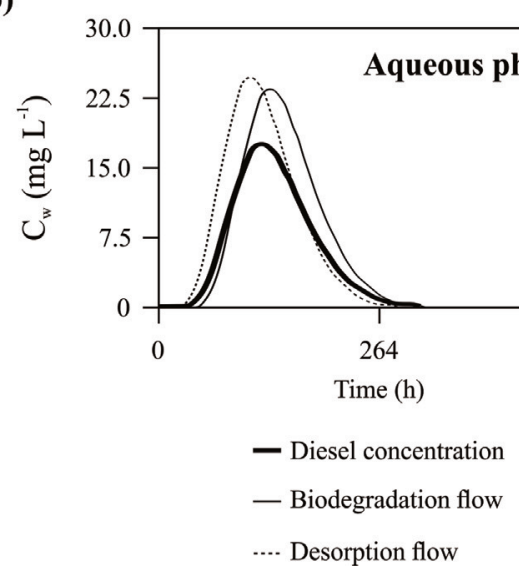

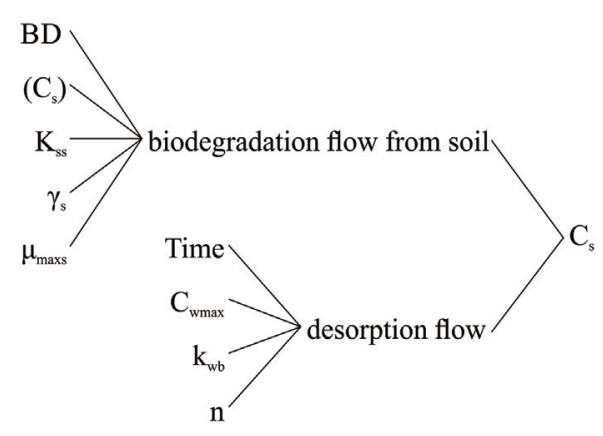

$\mathrm{BD}$

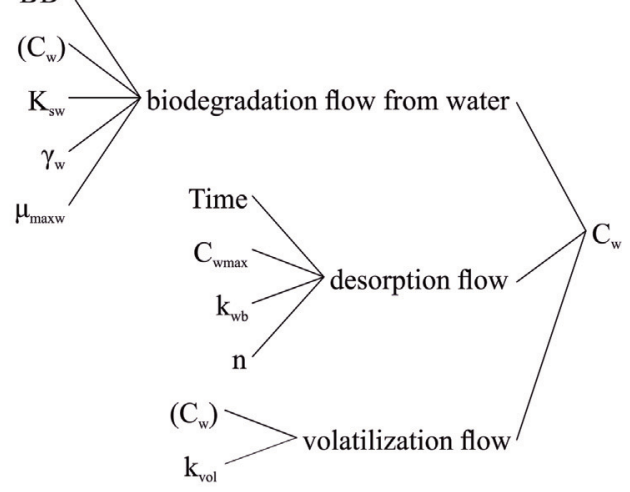

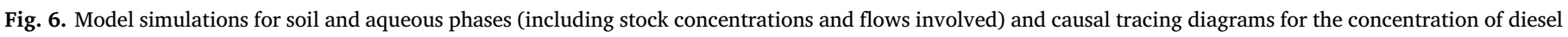
in (a) soil $\left(C_{s}\right)$ and (b) water $\left(C_{w}\right)$.

which $>90 \%$ elimination of diesel range organics was achieved after $528 \mathrm{~h}$. This indicates that the proposed bioreactor configuration and the operational parameters were favourable for diesel elimination and that the proposed system could be scaled up to design an industrial-scale bioreactor. The model was developed for a specific soil, diesel concentration and bacterial inoculant. However, adjustment of the corresponding parameters would enable the model to be adapted to other scenarios, including not only soils with different properties, but also sediments and sewage sludge, as well as different inoculation treatments, such as indigenous, exogenous and mixed bacterial populations. Further research is required to validate the model in a longer-term scenario and to ensure maintenance of a high bacterial density throughout the process; however, the model could serve as a basis for developing further models suited to a variety of soil systems, as well as 
for optimizing and developing in situ bioremediation procedures.

\section{Acknowledgements}

This research was supported by ERDF Interreg Sudoe Program (PhytoSUDOE-SOE1/P5/E0189) and by Hasselt University (BOF project 06G02 and Methusalem project 08M03VGRJ). M. Balseiro-Romero was granted a postdoctoral fellowship (Programa de axudas á etapa posdoutoral; ED481B 2017/073) by the Consellería de Cultura, Educación e Ordenación Universitaria (Xunta de Galicia, Spain). T. A. Lu-Chau belongs to the Galician Competitive Research Group GRC-ED431C 2017/ 29 and to CRETUS Strategic Partnership (ED431E 2018/01). M. Balseiro-Romero and C. Monterroso belong to the Galician Competitive Research Group GRC-ED431C 2018/12 and to CRETUS Strategic Partnership (ED431E 2018/01). All these programs are co-funded by ERDF.

\section{References}

Afzal, M., Yousaf, S., Reichenauer, T.G., Kuffner, M., Sessitsch, A., 2011. Soil type affects plant colonization, activity and catabolic gene expression of inoculated bacterial strains during phytoremediation of diesel. J. Hazard. Mater. 186, 1568-1575. https://doi.org/10.1016/j.jhazmat.2010.12.040.

Alavi, N., Mesdaghinia, A.-R., Naddafi, K., Mohebali, G., Daraei, H., Maleki, A., Alaei, L., 2014. Biodegradation of petroleum hydrocarbons in a soil polluted sample by oilbased drilling cuttings. Soil Sediment Contam. An Int. J. 23, 586-597. https://doi. org/10.1080/15320383.2014.847900.

Balseiro-Romero, M., Gkorezis, P., Kidd, P.S., Van Hamme, J., Weyens, N., Monterroso, C., Vangronsveld, J., 2017. Characterization and degradation potential of diesel-degrading bacterial strains for application in bioremediation. Int. J. Phytoremediation. https://doi.org/10.1080/15226514.2017.1337065.

Balseiro-Romero, M., Monterroso, C., 2018. Diesel-range organics extraction and determination in environmental samples by gas chromatography-mass spectrometry: headspace solid phase microextraction vs. solvent extraction. J. Anal. Chem. 73, 292-301. https://doi.org/10.1134/S1061934818030085.

Bezza, F.A., Nkhalambayausi Chirwa, E.M., 2016. Biosurfactant-enhanced bioremediation of aged polycyclic aromatic hydrocarbons (PAHs) in creosote contaminated soil. Chemosphere 144, 635-644. https://doi.org/10.1016/j.chemosphere.2015.08.027.

Borsi, I., Fasano, A., 2009. A general model for bioremediation processes of contaminated soils. Int. J. Adv. Eng. Sci. Appl. Math. 1, 33. https://doi.org/10.1007/s12572-0090003-x.

Bushnell, L.D., Haas, H.F., 1941. The utilization of certain hydrocarbons by microorganisms. J. Bacteriol. 41, 653-673.

Castaldi, F.J., 2003. Tank-based bioremediation of petroleum waste sludges. Environ. Prog. 22, 25-36. https://doi.org/10.1002/ep.670220114.

Chemlal, R., Abdi, N., Lounici, H., Drouiche, N., Pauss, A., Mameri, N., 2013. Modeling and qualitative study of diesel biodegradation using biopile process in sandy soil. Int. Biodeterior. Biodegrad. 78, 43-48. https://doi.org/10.1016/j.ibiod.2012.12.014.

Chemlal, R., Tassist, A., Drouiche, M., Lounici, H., Drouiche, N., Mameri, N., 2012. Microbiological aspects study of bioremediation of diesel-contaminated soils by biopile technique. Int. Biodeterior. Biodegrad. 75, 201-206. https://doi.org/10. 1016/j.ibiod.2012.09.011.

Dahalan, F.A., Yunus, I., Johari, W.L.W., Shukor, M.Y., Halmi, M.I.E., Shamaan, N.A., Syed, M.A., 2014. Growth kinetics of a diesel-degrading bacterial strain from petroleum-contaminated soil. J. Environ. Biol. 35, 399-406.

Day, M.J., Reinke, R.F., Thomson, J.A.M., 2001. Fate and transport of fuel components below slightly leaking underground storage tanks. Environ. Forensics 2, 21-28. https://doi.org/10.1006/enfo.2000.0036.

Fernández, E.L., Merlo, E.M., Mayor, L.R., Camacho, J.V., 2016. Kinetic modelling of a diesel-polluted clayey soil bioremediation process. Sci. Total Environ. 557-558, 276-284. https://doi.org/10.1016/j.scitotenv.2016.03.074.

Gallego, J.L.R., Loredo, J., Llamas, J.F., Vázquez, F., Sánchez, J., 2001. Bioremediation of diesel-contaminated soils: evaluation of potential in situ techniques by study of bacterial degradation. Biodegradation 12, 325-335. https://doi.org/10.1023/ A:1014397732435.

Gan, S., Lau, E.V., Ng, H.K., 2009. Remediation of soils contaminated with polycyclic aromatic hydrocarbons (PAHs). J. Hazard Mater. https://doi.org/10.1016/j.jhazmat. 2009.07.118.

Gkorezis, P., 2014. The Role of Plant-Associated Bacteria in the Remediation of Soils and Groundwater Contaminated with Petroleum Hydrocarbons. Dissertation, University of Hasselt.

Gkorezis, P., Daghio, M., Franzetti, A., Van Hamme, J.D., Sillen, W., Vangronsveld, J., 2016. The interaction between plants and bacteria in the remediation of petroleum hydrocarbons: an environmental perspective. Front. Microbiol. 7, 1836. https://doi. org/10.3389/fmicb.2016.01836.

IUSS Working Group WRB, 2014. World Reference Base for Soil Resources. International Soil Classification System for Naming Soils and Creating Legends for Soil Maps, World Soil Resources Reports No. 106. FAO, ROME. https://doi.org/10.1017/ S0014479706394902.
Kargi, F., 2009. Re-interpretation of the logistic equation for batch microbial growth in relation to Monod kinetics. Lett. Appl. Microbiol. 48, 398-401. https://doi.org/10. 1111/j.1472-765X.2008.02537.x.

Khan, S., Afzal, M., Iqbal, S., Khan, Q.M., 2013. Plant-bacteria partnerships for the remediation of hydrocarbon contaminated soils. Chemosphere 90, 1317-1332. https:// doi.org/10.1016/j.chemosphere.2012.09.045.

Lors, C., Damidot, D., Ponge, J.F., Périé, F., 2012. Comparison of a bioremediation process of PAHs in a PAH-contaminated soil at field and laboratory scales. In: Environmental Pollution, pp. 11-17. https://doi.org/10.1016/j.envpol.2012.02.004.

Maddela, N.R., Burgos, R., Kadiyala, V., Carrion, A.R., Bangeppagari, M., 2016. Removal of petroleum hydrocarbons from crude oil in solid and slurry phase by mixed soil microorganisms isolated from Ecuadorian oil fields. Int. Biodeterior. Biodegrad. 108, 85-90. https://doi.org/10.1016/j.ibiod.2015.12.015.

Megharaj, M., Ramakrishnan, B., Venkateswarlu, K., Sethunathan, N., Naidu, R., 2011. Bioremediation approaches for organic pollutants: a critical perspective. Environ. Int. 37, 1362-1375. https://doi.org/10.1016/j.envint.2011.06.003.

Mosca Angelucci, D., Tomei, M.C., 2016. Ex situ bioremediation of chlorophenol contaminated soil: comparison of slurry and solid-phase bioreactors with the two-step polymer extraction-bioregeneration process. J. Chem. Technol. Biotechnol. 91, 1577-1584. https://doi.org/10.1002/jctb.4882.

Nano, G., Borroni, A., Rota, R., 2003. Combined slurry and solid-phase bioremediation of diesel contaminated soils. J. Hazard. Mater. 100, 79-94. https://doi.org/10.1016/ S0304-3894(03)00065-7.

Pansu, M., Gautheyrou, J., 2006. Handbook of Soil Analysis: Mineralogical, Organic and Inorganic Methods, Handbook of Soil Analysis: Mineralogical, Organic and Inorganic Methods. Springer-Verlag, Heidelberg. https://doi.org/10.1007/978-3-540-31211-6.

Pilon-Smits, E., 2005. Phytoremediation. Annu. Rev. Plant Biol. 56, 15-39. https://doi. org/10.1146/annurev.arplant.56.032604.144214.

Pino-Herrera, D.O., Pechaud, Y., Huguenot, D., Esposito, G., van Hullebusch, E.D., Oturan, M.A., 2017. Removal mechanisms in aerobic slurry bioreactors for remediation of soils and sediments polluted with hydrophobic organic compounds: an overview. J. Hazard. Mater. 339, 427-449. https://doi.org/10.1016/j.jhazmat.2017. 06.013.

Robles-González, I.V., Fava, F., Poggi-Varaldo, H.M., 2008. A review on slurry bioreactors for bioremediation of soils and sediments. Microb. Cell Factories 7, 5. https://doi. org/10.1186/1475-2859-7-5.

Semple, K.T., Morriss, A.W.J., Paton, G.I., 2003. Bioavailability of hydrophobic organic contaminants in soils: fundamental concepts and techniques for analysis. Eur. J. Soil Sci. 54, 809-818. https://doi.org/10.1046/j.1351-0754.2003.0564.x.

Serrano, A., Gallego, M., González, J.L., Tejada, M., 2008. Natural attenuation of diesel aliphatic hydrocarbons in contaminated agricultural soil. Environ. Pollut. 151, 494-502. https://doi.org/10.1016/j.envpol.2007.04.015.

Simpanen, S., Mäkelä, R., Mikola, J., Silvennoinen, H., Romantschuk, M., 2016. Bioremediation of creosote contaminated soil in both laboratory and field scale: investigating the ability of methyl- $\beta$-cyclodextrin to enhance biostimulation. Int. Biodeterior. Biodegrad. 106, 117-126. https://doi.org/10.1016/j.ibiod.2015.10.013.

Skrdla, P.J., 2007. A simple model for complex dissolution kinetics: a case study of norfloxacin. J. Pharm. Biomed. Anal. 45, 251-256. https://doi.org/10.1016/j.jpba. 2007.06.012.

Suja, F., Rahim, F., Taha, M.R., Hambali, N., Rizal Razali, M., Khalid, A., Hamzah, A., 2014. Effects of local microbial bioaugmentation and biostimulation on the bioremediation of total petroleum hydrocarbons (TPH) in crude oil contaminated soil based on laboratory and field observations. Int. Biodeterior. Biodegrad. 90, 115-122. https://doi.org/10.1016/j.ibiod.2014.03.006.

Szulc, A., Ambrożewicz, D., Sydow, M., Ławniczak, Ł., Piotrowska-Cyplik, A., Marecik, R. Chrzanowski, Ł., 2014. The influence of bioaugmentation and biosurfactant addition on bioremediation efficiency of diesel-oil contaminated soil: feasibility during field studies. J. Environ. Manag. 132, 121-128. https://doi.org/10.1016/j.jenvman.2013. 11.006.

Tomei, M.C., Daugulis, A.J., 2013. Ex situ bioremediation of contaminated soils: an overview of conventional and innovative Technologies. Crit. Rev. Environ. Sci. Technol. 43, 2107-2139. https://doi.org/10.1080/10643389.2012.672056.

Tyagi, M., da Fonseca, M.M.R., de Carvalho, C.C.C.R., 2011. Bioaugmentation and biostimulation strategies to improve the effectiveness of bioremediation processes. Biodegradation 22, 231-241. https://doi.org/10.1007/s10532-010-9394-4.

US Environmental Protection Agency (US EPA), 2007. Method 3545A: Presurized Fluid Extraction (PFE). Revision 1.

Venkata Mohan, S., Prasanna, D., Purushotham Reddy, B., Sarma, P.N., 2008. Ex situ bioremediation of pyrene contaminated soil in bio-slurry phase reactor operated in periodic discontinuous batch mode: influence of bioaugmentation. Int. Biodeterior. Biodegrad. 62, 162-169. https://doi.org/10.1016/j.ibiod.2008.01.006.

Venkata Mohan, S., Purushotham Reddy, B., Sarma, P.N., 2009. Ex situ slurry phase bioremediation of chrysene contaminated soil with the function of metabolic function: process evaluation by data enveloping analysis (DEA) and Taguchi design of experimental methodology (DOE). Bioresour. Technol. 100, 164-172. https://doi. org $/ 10.1016 /$ j.biortech.2008.06.020.

Wang, S.Y., Kuo, Y.C., Hong, A., Chang, Y.M., Kao, C.M., 2016. Bioremediation of diesel and lubricant oil-contaminated soils using enhanced landfarming system. Chemosphere 164, 558-567. https://doi.org/10.1016/j.chemosphere.2016.08.128.

Xia, W., Du, Z., Cui, Q., Dong, H., Wang, F., He, P., Tang, Y., 2014. Biosurfactant produced by novel Pseudomonas sp. WJ6 with biodegradation of n-alkanes and polycyclic aromatic hydrocarbons. J. Hazard. Mater. 276, 489-498. https://doi.org/10. 1016/j.jhazmat.2014.05.062. 